\title{
Middle Permian Sedimentary Cycles and Facies Features in the Tieqiao Section in Laibin, Guangxi, South China
}

\author{
Yao Yao*
}

School of Earth Sciences and Resource, China University of Geosciences, Beijing 10083, China

\begin{abstract}
In the Late Paleozoic paleogeography, the Laibin area, South China, locates in the south-eastern margin of the Laibin-Heshan isolated carbonate platform. One global stratotype section for The Guadalupian-Lopingian (G/L) (The end of the Mid-Permian) transition is located in the Tieqiao section in Laibin area, which is regarded as appropriate one for the study. Based on the analysis, seven facies (open platform, restricted platform, neritic shelf, bioclastic shoal, reef, slope, and basin) are recognized in the Maokouan Formations, besides, three sequences have been identified in the Maokouan succession. They all represent a deeping-upward then shallowing-upward sedimentary cycle, and the microfacies alternation conformable marine sequences at that time, which implies consistence of sequence number recorded in the Tieqiao section were little influenced by the role of sys-depositional fault, maybe controled by the paleoceanographic condition.
\end{abstract}

Keywords: Maokouan (middle permian), sedimentary features, sedimentary microfacies.

\section{INTRODUCTION}

Isolated carbonate platform is often surrounded by deepwater sediments in the deep basin, as a special kind of shallow-water carbonate platform, different from the attached carbonate platform [1-3]. This unattached platform, such as the Florida-Bahamas region, occur in subsiding passive margin basins where the basements are characterised by different subsidence rates $[4,5]$. Late Paleozoic, the Guizhou-Guangxi basin under extensional tectonic background with sysdepositional faulting [6], presented a number of various sizes isolated carbonate platforms which constituted a exceptional Palaeogeographic-carbonate platforms in shallow water and siliceous/argillaceous basins in deep water were alternate arrangement [7]. These carbonate platforms formed in shallow water begining at the late Devonian, and then expanding durning the Carboniferous, and the Late Permian began to shrink [8] (Fig. 1). Therefore, most studies of the sedimentary evolution have concentrated in basement tectonic setting and contemporaneous faulting [9].

The Guadalupian-Lopingian boundary (GLB) (Middle Permian) is a critical time interval which includes one of the major catastrophe, this extinction event coincides with many sedimentation anomalies. The Tieqiao Section around Laibin area of Guangxi record deposition of GLB succession is considered to be continuous [10,11], and thus is chosen for this study. The section of Tieqiao along the southeastern edge of Laibin-Heshan carbonate platform, for i) the deposition characteristics of this platform margin ; ii) the evolution of this platform margin within the transition from platform to basin ;still lack a clear understanding. It should be noted that around the study site, the sedimentary facies have not been accurately documented or described. This study attempt to examine the microfacie and facie changes during the Maokou formation.

\section{PALEOGEOGRAPHIC AND STRATIGRAPHIC SETTINGS}

During the Late Paleozoic, Laibin-Heshan carbonate platform lay along the east of Guizhou-Guangxi Basin, which northwest flanked by the Yongfu-Laibin Fault. The Tieqiao section is along the north bank of the Hongshui River, $5 \mathrm{~km}$ southeast of Laibin town, deposited along the western margin of Laibin Syncline. At this stratotype section, the Permian succession is subdivided into the Qixia, Maokou, Wujiaping and Dalong Formations in ascending order [12].

The lower Qixia Formation correspond to Liangshan Group, which consists of interbedded dark gray, mediumthin bedded bioclastic limestone and dark thin bedded mudstone, the surface of limestone is rich of brachiopod, bryozoan and crinoid bioclasts. These are followed by medium-thick or block, dark gray bioclastic limestone, banded or layered chert phthisis was intermittent distribution. there are wide range of biodetritus, such as calcareous algaes and corals, which indicated the shallow-water carbonate platform facies. The bed thickness, bioclastic types and quantity shows a gradual decrease in water depth characterizes depositional environment of the upper Qixia Formation, that is contrary with the Yangtze craton stratigraphic sequenceate.

There are three high-frequency cycles can be recognized in Maokou Formation, the lower cycle composition paralleled to the Qixia Formation; and the overlying cycles of the upper Maokou Formation are distinctly chert and silicified limestone, and the massive light colour limestone only appear at the top of this two cycles (Fig. 2). 


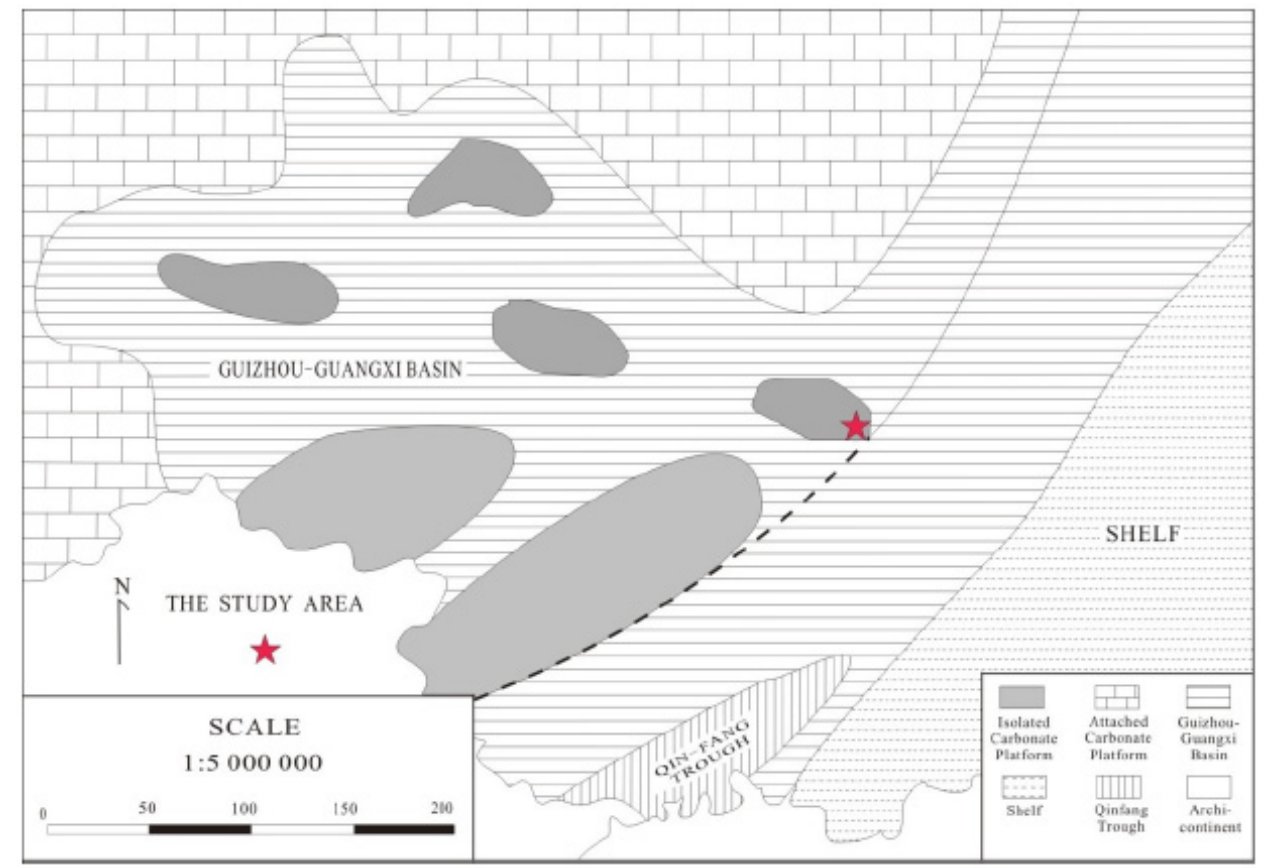

Fig. (1). Geological setting and location of the study section.

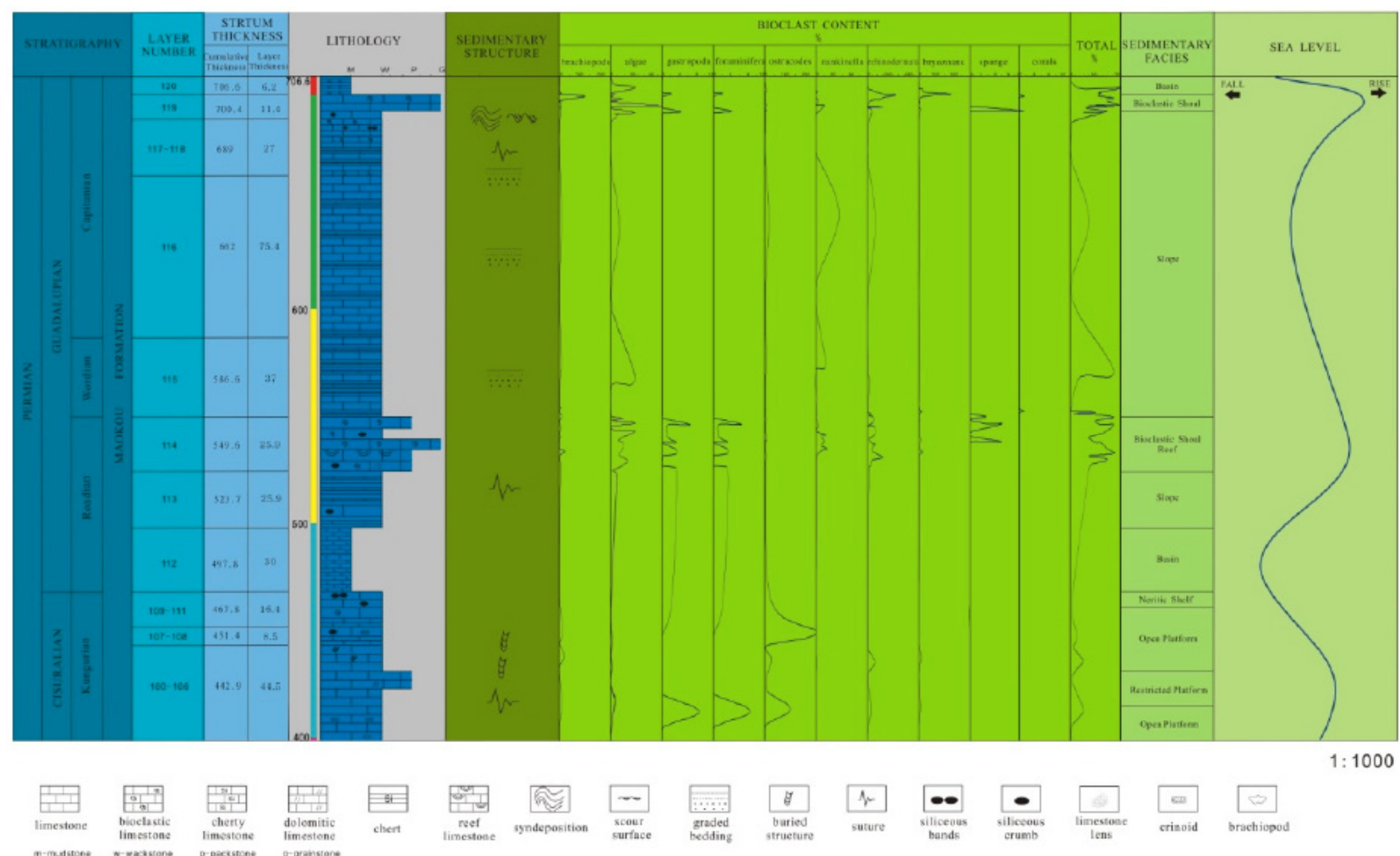

Fig. (2). Lithology, sedimentary facies and structures, bioclast contents and relative sea-level change curve for the middle permian succession at the tieqiao section.

The lower Wujiaping Formation still consists of chert, cherty limestone, and that marks the onset of deep-water conditions. Where reef limestone is present in the middleupper Wujiaping Formation, then it become cherty limestone in the uppermost. The Dalong Formation is mainly composed of gray, dark gray, thin bedded chert and siliceous shale, indicating relatively basinal deposition [12].
As previously mentioned, stratigraphic sequence shows that it is typically the shallow-water platform facies of the Qixia-Maokou Period at Tieqiao Section in Laibin aera, and a belt of transition between the deep-water platformal slopebasin faciess and the shallow-water platform platform margin reef facies continental during the mid-late Maokou Pe- 
riod to Wujiaping Period, the platform drowning occured in the stage of Dalong Period.

\section{SEDIMENTARY FEATURES OF MAOKOU FOR- MATION}

\subsection{Carbonate Rocks of the Lower Maokou}

As mentioned above, three cycles that record facies changes can be recognized at Maokou Formation. The first cycle, including 100 to 110 layers (layer number follows [12]), consists of bioclastic wackstone and mudstone. Two thin bedded bioclastic limestone, riching of brachiopods (Fig. 3a), have been found at the base of this cycle, which marked the boundary with the underlying strata. The lower beds consists of dark-grey medium bedded, coarse-grained bioclastic wackstone (Fig. 3b), then thin bedded argillaceous limestone appeared at the intermediate section. In addition, zoophycos trace fossils occurred in the limestone (Fig. 3c) [13]. Chert nodules appear at the upper beds, and overlain by dolomitic limestone (0.3m) (Fig. 3d). Gastropods, brachiopods, foraminifers, ostracodes and crinoids as well as little algae comprise the bioclastic limestone, but lack of the typical deep-water fossils, that indicated the open platform facies mainly in this cycle, and the dolomitic limestone of the top stratum may belong restricted platform facies.
It should be noted that the 111 layer consists of chert intercalated with limestone $(0.2-0.5 \mathrm{~m})$, indicating the second cycle depositional setting. Horizontal bedding mainly occurs in this bed. limestone is mainly composed of mudstone, rarely include some Biotic fragments. The lamination indicated ocean anoxia, which leaded to a substantial reduction in productivity. The reduction of bioclasts contrasted with the increase of siliceous bands means the water depth is greater than the depositional environment of the first cycle. Microscopic observation, lacking of appropriate evidence gravity flow deposits, reveals that 111 layer deposition environment may give priority to the shelf facies.

\subsection{Formation Siliceous Rock of the Middle-Upper Maokou Formation}

The 112 layer(the middle of the second cycle in Maokou Formation) (Fig. 2) comprises grey to dark grey, mediumthin bedded chert. Biotype are dominated by radiolarians and sponge spicules, as well as rare small foraminifers and extremely fine-grained shallow water bioclast. The main types of microfacies are silicite and radiolarian-sponge spicule mudstone. This reveals the basin facies on account of the thin beds, dark sediments, low biological abundance and diversity along with the absence of benthos.

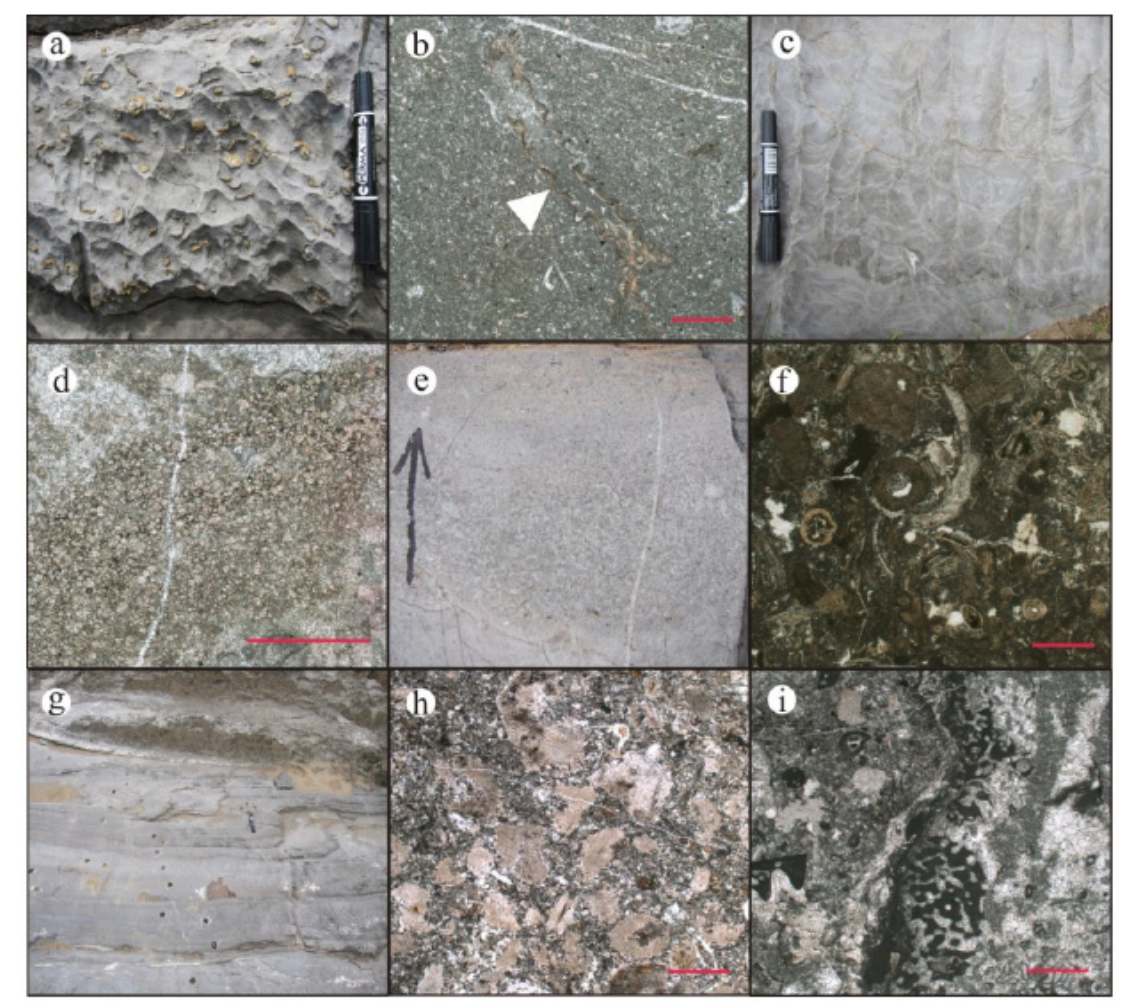

Fig. (3). Field Exposures and Microphotos of the Maokou Formation. (a) Bioclastic Limestone with Brachiopod of the Lower Maokou Formation at 100 Layer. (b) Photomicrographs of Bryozoans Bioclastic Wackstone of the Lower Maokou Formation at 100 Layer, Note That Bryozoans(Indicated by Arrows) Ffilled by Micrite Calcite; Scale Bar 0.5mm. (c) Zoophycos Trace Fossils Occurred in the Limestone of the Lower Maokou Formation at 105 Layer. (d) Photomicrographs of Dolomitic Limestone of the Lower Maokou Formation at 110 Layer; Scale Bar 0.5mm. (e) Normal Graded Bedding of the Middle Maokou Formation at 115 Layer. (f) Photomicrographs of Bioclastic Packstone in Grain Flow of the Upper Maokou Formation at 116 Layer; Scale Bar 0.5mm. (g) Syndepositional Deformation of the Upper Maokou Formation at 119 Layer. (h) Photomicrographs of Crinoids Grainstone of the Upper Maokou Formation at 119 Layer; Scale Bar 0.5mm. (i) Photomicrographs of Sponge-Algal-Tubiphytes Bafflestone of the Middle Maokou Formation at 114 Layer; Scale Bar 0.5mm. 
The middle-upper section of the second cycle and the third cycle consist of the light grey,medium bedded chert and siliceous limestone intercalated with limestone nodules and lens in Maokou Formation. The 116 to 117 layers are represented by light grey, medium limestion, which are characterized by a typical rhythmic texture with the thin bedded chert and siliceous limestone. Gravity flow sediments are well developed in the entire sequences, especially in the medium bedded limestone. Gravity flow gives priority to turbidity currents (Fig. 3e), with rare grain flow. Biotic fragments preserve well in grain flow, including foraminifers, nankinella, echinodermata and brachiopods (Fig. 3f). Biotic fragments sediments in situ consist of radiolarians, sponge spicules and few epibenthos, which mainly composed of fine-silty sand and difficult to identify the specific categories.

Thin siliceous rock beddings present distorted between 115 to 119 layers. It is difficult to determine the influence of primary sedimentary structure or late tectonic movement, with the consideration of entirely thin chert, siliceous limestone sequence, which thickness is nearly one hundred meters. After identifying the syndepositional deformation (Fig. 3g) and gravity current sediments evidence, it considered that the slope facies appear at 113 layer and 115-119 layers.

\subsection{Carbonate Rocks of the Middle-Upper Maokou Formation}

114 layer and 119 layer (Laibin Limestone) (Fig. 2) consist of shallow-water limestone. Chen et al. [14] reported bioherm is developed in the limestone of 119 layer, where Wignall et al. [15] confirmed Laibin Limestone formed on the slope depositional environment. Through field observations, crinoids bioclasts grainstone occur at the upper part of Laibin Limestone (Fig. 3h), which shows the characteristics of high energy biological detritus bank. And in the lower part of the strata, massive limestone dominated by abundant brachiopods and characterized by in-place organic structure suggesting a subtidal high-energy zone to neritic continental shelf environment.

114 layer outcrops is mainly composed of grey-wight massive bedded limestone ( $34 \mathrm{~m}$ thick). Thin section analysis reveals that three microfacies are recognized in this facies association: bioclastic wackstone-packstone, sponge-algaltubiphytes bafflestone and bioclastic grainstone. Biotic fragments preserve well in bioclastic wackstone-packstone, including brachiopods, bryozoans, tubiphytes, echinodermata, ungdarella and foraminifers. Considering the algaes and tubiphytes may play a bonding role in the process of the reefs development (Fig. 3i), the microfacies characteristics indicates a reef environment. Biotic fragments are abundant in the the thin bedded grainstone, which not only includes some bioclasts of crinoid, corals, foraminifera and tubiphytes, but also a few gastropoda, ostracodes and algae (such as ungdarella, dasycladales). Rock texture and biological feature from the locality implying that they were deposited at high-energy organic bank.

\section{CONCLUSION}

(1) Seven facies types are recognized at Tieqiao section, including open platform (bioclastic wackstone microfacies and bioclastic packstone microfacies), restricted platform (dolomitic limestone microfacies), neritic shelf (mudstone microfacies), bioclastic shoal (bioclasts grainstone microfacies), reef (sponge-algal-tubiphytes bafflestone microfacies), slope (bioclastic wackstone microfacies and silicite microfacies) and basinal (silicite microfacies and radiolarian-sponge spicule mudstone microfacies).

(2) In the Laibin area, three main transgressive-regressive (TR) sequences are identified in strata from the Tieqiao section (Middle Permian); they are corresponding to three cycles of sea level changes. This trend may reflect that LaibinHeshan isolated carbonate platform began to shrink during this period, and ancient ocean conditions affect the sedimentary sequence need further study.

\section{CONFLICT OF INTEREST}

The author confirms that this article content has no conflict of interest.

\section{ACKNOWLEDGEMENTS}

This work is supported by the National Natural Science Foundation of China (No.41472090, No.40472065, No.49802012).

\section{REFERENCES}

[1] J. L. Wilson, "Carbonate Facies in Geologic History," Springer Verlag, New York, pp. 1-470, 1975.

[2] E. Gischler, I. Hauser, K. Heinrich, and U. Scheitel, "Characterization of depositional environments in isolated carbonate platforms based on Benthic Foram in ifera, Belize, Central America", Palaios, vol.18, no.3, pp. 236-255, 2003.

[3] E. Flügel, "Microfacies of Carbonate Rocks: Analysis, Interpretation and Application," Springer-Verlag: Berlin Heidelberg, pp. 1639, 2004.

[4] D. Bosence, "A genetic classification of carbonate platforms based on their basinal and tectonic settings in the Cenozoic", Sedimentary Geology, vol. 175, no.1-4, pp. 49-72, 2005.

[5] J. Y. Gu, F. Ma, and L. D. Ji, "Types, characteristics and main controlling factors of carbonate platform", Journal of Paleogeography, vol. 11, no.1, pp. 22-26, 2009. (in Chinese with English abstract).

[6] H. R. Wu, "Discussion on tectonic palaeogeography of Nanpanjiang sea in the Late Palaeozoic and Triassic", Journal of Palaeogeography, vol. 5, no.1, pp. 63-76, 2003. (in Chinese with English abstract).

[7] G. Shi, J. C. Tian, X. Zhang, R. Li, and M. Y. Yu, "The sedimentary characteristics, evolution and controlling factors of southern margn, Yangtze carbonate platform during the HercynianIndosinian stage", Geoscience, vol. 23, no.6, pp. 1114-1120, 2009 ( in Chinese with English abstract).

[8] Y. S. Ma, H. D. Chen, and G. L. Wang, Tectonic-Sequence-Based Lithofacies and Paleogeography Atlas in South China, Science Press, Beijing, pp. 158-224, 2009. (in Chinese).

[9] H. Y. Yang, S. Y. Chen, X. L. Hao, H. Gao, C. Li, and Y. Yang, "Sedimentary characteristics and evolutionary stages of late Paleozoic Longlin isolated platform in Nanpanjiang depression", Geology in China, vol. 37, no.6, pp. 1638-1646, 2010. ( in Chinese with English abstract).

[10] Y. G. Jin, Q. H. Shang, and C. Q. Cao, "A review of Permian stratigraphy", Journal of Stratigraphy, vol.24, no.2, pp. 99-108, 2000. (in Chinese with English abstract).

[11] Y. G. Jin, S. Z. Shen, C, M, Henderson, X. D. Wang, W. Wang, Y. Wang, C. Q. Cao, H. Q. Shang, and Q. F. Zheng, "The global stratotype section and point (GSSP) for the boundary between the Guadalupian and Lopingian series(Permian)", Journal of Stratigraphy, vol. 29, no.4, pp. 253-262, 2006. (in Chinese with English abstract). 
[12] Q. A. Sha, W. S. Wu, and J. M. Fu, Comprehensive Research on Permian in Guizhou-Guangxi Area and its Petroleum Potential, Science Press, Beijing, pp.1-215, 1990. (in Chinese).

[13] Y. M. Gong, R. Xu, S. C. Xie, X. Y. Huang, B. Hu, Y. A. Qi, and G. C. Zhang, "Microorganism and elementary fossil in Vestigiofossil Zoophycos", Science in China, vol. 37, no.6, pp. 713-719, 2007. (in Chinese with English abstract).

[14] Z. Q. Chen, A. D. George, and W. R. Yang, "Effects of midlelate Permian sea-level changes and mass extinction on the forma- tion of the Tieqiao skeletalmound in the Laibin area", South China. Australian Journal of Earth Sciences, vol. 56, no.6, pp. 745-763, 2009.

[15] P. B. Wignall, S. Vdrine, D. P. G. Bond, W. Wang, X. L. Lai, J. R. Ali, and H. S. Jiang, "Facies analysis and sea-level change at the Guadalupian-Lopingian global stratotype (Laibin, South China), and its bearing on the end-Guadalpian mass extinction", Journal of the Geological Society, vol.166, pp. 655-666, 2009.

Received: June 10, 2015

(C) Yao Yao; Licensee Bentham Open.

This is an open access article licensed under the terms of the Creative Commons Attribution Non-Commercial License (http://creativecommons.org/licenses/by-nc/3.0/) which permits unrestricted, non-commercial use, distribution and reproduction in any medium, provided the work is properly cited. 